(and other) indices were measured in several hundred people and then subsequent coronary or cerebrovascular events recorded. In the Northwick Park Heart Study of 1511 white men aged 40 to 64 at recruitment both high factor VII activity and high plasma fibrinogen concentrations were strongly associated with ischaemic heart disease. ${ }^{34}$ In both cases the association was particularly strong for the subgroup of men who developed heart disease within five years of their blood being examined. The findings are intriguing in that the associations with coagulation factors seem stronger than that between cholesterol concentrations and heart disease. Fibrinogen concentration has also been identified as a risk marker in a smaller prospective study of coronary disease ${ }^{5}$ and in a prospective study of myocardial infarction and stroke. ${ }^{6}$ In other investigations a high white cell count has also proved to be a risk marker for myocardial infarction and stroke. $^{78}$

In general the incidence of thrombotic disease in black people is lower than that in whites, and findings that blood from healthy whites is "hypercoagulable" or displays a lower fibrinolytic activity, or both, when compared with blood from healthy blacks ${ }^{910}$ support the concept that blood composition may contribute to developing thrombosis. Until recently, reports of coagulation and fibrinolytic studies in different ethnic groups have been limited to subjects in one geographic locality because haematological indices can be compared only if methods are standardised. Standardisation is often difficult between adjacent laboratories, never mind countries, but, using continuous external quality control of the laboratory measurements, the World Health Organisation has started a study to compare the effects of different oral contraceptives on coagulation, fibrinolysis, and platelet "function" in women from diverse geographical locations. A recent article records the baseline data from clinical centres in Dublin, Salvador (Brazil), Santiago (Chile), and Singapore. ${ }^{11}$ The women in the study are to be given oral contraceptives, which makes the decision to study these particular centres surprising given the Catholic influence in some of them, and women recruited in, for example, Dublin are unlikely to be a completely random sample.

Data were provided for just under 200 women at each centre. Not all of it stood up to the external quality control, but the information was sufficient for some clear patterns to emerge. The most interesting data came from Dublin (where all the women were white) and from Salvador (where the women were predominantly black or mulatto). Blood from the Dublin women turned out to be "hypercoagulable" (short prothrombin time, short activated partial thromboplastin time, increased factor $\mathrm{X}$ activity, and increased concentration of antiplasmin) while that from the Salvador women turned out to be "hypocoagulable" (prolonged prothrombin time, prolonged activated partial thromboplastin time, lower factor VII activity, increased plasminogen activator activity, and decreased concentrations of antiplasmin). In contrast, the Dublin women had higher concentrations of antifactor $\mathrm{Xa}$ and antithrombin III (which may, the authors suggest, protect against the hypercoagulability), and the Salvador women had lower concentrations of these antiproteases. Unfortunately information on white cell counts was incomplete and the platelet studies were not fully standardised.

The authors of the report consider the data in terms of 'the clinical impression that the 'epidemic' of thromboembolism ... in Western countries has not been shared by the developing parts of the globe where clinical evidence of thromboembolism is relatively rare." A critical study of venous thrombosis in Nigerians questioned, however, the previous largely clinical impression of a lower incidence of the disease in this population. ${ }^{12}$ The WHO investigators must now copy Meade $e t a l^{4}$ and follow up the patients ${ }_{c}$ to determine the actual rates of thrombosis. Some informa- tion may be obtained as a byproduct of giving oral con- $\frac{\rho}{\bar{F}}$ traceptives-provided that the group studied is large enough and the procedures adopted to detect thrombosis well ${ }^{\infty}$ standardised.

Prospective and large scale comparative studies (particularly in diverse geographical locations) are expensive and require much organisation and energy, huge resources, ando good quality control. Nevertheless, this type of study will tell us most about the aetiology of thrombosis-information of $\frac{\bar{c}}{\overline{0}}$ fundamental importance if the disease is to be controlled. $\stackrel{\Phi}{\circ}$

$S$ HEPTINSTALL $\vec{\circ}$

Senior Lecturer,

Department of Medicine,

University Hospital

Nottingham NG7 2UH

1 Gallus AS, Hirsch J, Gent M. Relevance of preoperative and postoperative blood tests too postoperative leg-vein thrombosis. Lancet 1973;ii:805-9.

2 Clayton JK, Anderson JA, McNicol GP. Preoperative prediction of postoperative deep vein $\mathcal{S}_{\mathrm{W}}$ thrombosis. Br Med $\mathcal{T}$ 1976;ii:910-2.

3 Meade TW, North WRS, Chakrabarti R, Stirling Y, Haines AP, Thompson SG. Haemostatic + के function and cardiovascular death: early results of a prospective study. Lancet 1980;i:1050-4. 윽

4 Meade TW, Mellows S, Brozovic M, et al. Haemostatic function and ischaemic heart disease: $\omega$ principal results of the Northwick Park Heart Study. Lancet 1986;ii:533-7.

Stone MC, Thorpe JM. Plasma fibrinogen-a major coronary risk factor. I $R$ Coll Gen Pracos 1985;35:565-9.

6 Wilhelmsen L, Svardsudd K, Korsan-Bengtsen K, et al. Fibrinogen as a risk factor for stroke and으 myocardial infarction. $N$ Engl f Med 1984;311:501-5.

Friedman GD, Klatsky AL, Siegelaub AB. The leucocyte count as a predictor of myocardial infarction. $N$ Engl I Med 1974;290:1275-8. Prentice RL, Sztrowski TP, Kato H, Mason MW. Leukocyte counts and cerebrovascular disease. $\infty$ J Chronic Dis 1982;35:703-14.

Meade TW, Brozovic $M$, Chakrabarti $R$, et al. Ethnic group comparisons of variables associated

with ischaemic heart disease. Br Heart $\mathcal{F}$ 1978;40:789-95.
10 Szceklik A, Dischinger $P$, Kueppers F, et al. Blood fibrinolytic activity, social class and habitual physical activity. II. A study of black and white men in Southern Georgia. I Chronic Dis 1980;33:291-9.

11 Bocaz JA, Barja P, Bonnar J, et al. Differences in coagulation and haemostatic parameters in normal women of childbearing age from different ethnic groups and geographical locations. $\mathcal{Q}$ Thromb Haemost 1986;55:390-5.

12 Osime U. Incidence of postoperative deep vein thrombosis in Nigerians using ${ }^{125}$ I-labelled fibrinogen. Br Med $\mathcal{J} 1978$;ii: 1607 .

\section{Coffee, cholesterol, and colon cancer: is there a link?}

Drinking coffee may raise serum cholesterol concentrations $\rightarrow$ The association was first observed by Bjelke in Norway in $1974^{1}$ and has since been confirmed in three much largero Norwegian studies, one of which has been published in $\omega$ detail. ${ }^{2}$ The association has also been ohserved in some, but not all, studies from other countries. ${ }^{3.7}$ That coffee (at leaste coffee brewed in the north Norwegian way) may actuallyo cause the rise in cholesterol concentration has been suggested by two small experiments. ${ }^{89}$.

Coffee drinking may also be associated with a reduced risk $\stackrel{\mathrm{D}}{\stackrel{\mathrm{D}}{\mathrm{S}}}$ of developing cancer of the colon. Bjelke found this to be so in his case-control studies with 162 cases in Norway and 2590 cases in Minnesota, ${ }^{10}$ and similar findings have been reportedo from two other case-control studies. ${ }^{112}$ But no associatione was seen in two other case-control studies, ${ }^{1314}$ and in a thirdô. "a significant but small excess risk" of colon cancer was associated with high coffee consumption. ${ }^{15}$ 
In a follow up in Norway of 16555 people (mostly men) ${ }^{16}$ coffee drinking was negatively associated with the incidence of colon cancer. There was, however, a linear interaction with age, the lowest relative risk being in the youngest. For those under 65 at the start of $11 \frac{1}{2}$ years' follow up a strong statistically significant negative relation was seen, whereas a non-significant positive association was seen in older individuals. A positive association between coffee drinking and death from colon cancer has been reported from an Adventist cohort, ${ }^{11}$ whereas no association was seen between coffee consumption and risk of colon cancer in Japanese men in Hawaii. ${ }^{18}$ The coffee consumption in both of these cohorts was considerably lower than that in the Norwegian cohort. Another explanation for the finding in Adventists may be that coffee consumption shows poor adherence to the lifestyle recommended by the church. Furthermore, the positive association was limited to the last 11 of 21 years' follow up.

How can these associations be explained? Our proposal, which is in line with what Bjelke suggested 12 years ago, ${ }^{1}$ is that coffee contains substances that reduce the excretion of bile acids or neutral sterols, or both, thereby reducing the risk of colon cancer but increasing the serum cholesterol concentration. Bile acids, particularly secondary bile acids, are potent promoters of colon carcinogens in animals. Furthermore, groups with diets associated with a high risk of colon cancer have an increased excretion of sterol metabolites, and higher faecal bile acid concentrations have been found in patients with colorectal cancer than in controls. ${ }^{19}$ Lowenfels has proposed that in some of those who consume a high cholesterol, high fat diet a lower serum cholesterol concentration indicates increased cholesterol excretion ${ }^{20}$ - thereby explaining the inverse relation between serum cholesterol and the risk of colon cancer, ${ }^{21}$ an association which still is under debate. ${ }^{22}$ The mechanism we propose linking coffee consumption with increased cholesterol concentration but reduced risk of colon cancer may operate only in groups with a high fat intake. This could explain the positive (or absent) association between coffee drinking and risk of colon cancer seen in Adventists ${ }^{17}$ and the Japanese in Hawaii. ${ }^{18}$

We know of no data on the effect of coffee consumption on bile acid and neutral sterol excretion from the liver in man. A significant physiological effect of coffee on liver metabolism is, however, suggested by Arnesen et al, who have shown an inverse relation between coffee drinking and $\gamma$-glutamyltransferase activity in the Troms $\varnothing$ populationeven after adjustment for other variables, including alcohol consumption. ${ }^{23}$

We believe that the repeated findings of a positive relation between coffee consumption and serum total cholesterol concentration and a reduced risk for cancer of the colon, at least in the Norwegian population, make it reasonable to examine in man the interrelation between coffee (brewed in different ways), bile excretion, and cholesterol metabolism.

\section{BJARNE K JACOBSEN}

Research fellow of the Norwegian Council on Cardiovascular Disease

DAg S THELle Professor

Institute of Community Medicine,

University of Troms $\varnothing$,

9001 Troms $\varnothing$,

Norway
1 Bjelke E. Colon cancer and blood-cholesterol. Lancet 1974;i:1116-7.

2 Thelle DS, Arnesen E, Førde OH. The Troms $\emptyset$ heart study. Does coffee raise serum cholesterol? N Engl I Med 1983;308:1454-7.

3 Mathias S, Garland C, Barrett-Connor E, Wingard DL. Coffee, plasma cholesterol, and lipoproteins. A population study in an adult community. Am f Epidemiol 1985;115:896-905.

4 Kark JD, Friedlander Y, Kaufmann NA, Stein Y. Coffee, tea, and plasma cholesterol: the Jerusalem Lipid Research Clinic prevalence study. Br Med F 1985;291:699-704.

5 Haffner SM, Knapp JA, Stern MP, Hazuda HP, Rosenthal M, Franco LJ. Coffee consumption, diet, and lipids. Am J Epidemiol 1985;122:1-12.

6 Curb JD, Reed DM, Kautz JA, Yano K. Coffee, caffeine, and serum cholesterol in Japanese men in Hawaii. Am $\mathcal{F}$ Epidemiol 1986;123:648-55.

7 Dawber TR, Kannel WB, Gordon T. Coffee and cardiovascular disease. Observations from the Framingham study. N Engl I Med 1974;291:871-4.

8 Arnesen E, Forde OH, Thelle DS, Coffee and serum cholesterol. Br Med f 1984;288:1960.

9 . Arnesen E, Førde OH, Thelle DS, Coffee and serum cholesterol. Br Med f 1984;288:1960. serum lipid concentrations in men with hypercholesterolaemia: a randomised intervention serum lipid concentrations in men
study. $B r$ Med $\mathcal{F} 1985 ; 290: 893-5$. .

10 Bjelke E. Epidemiological studies of cancer of the stomach, colon and rectum; with special emphasis on the role of diet. Vols 2-4. Ann Arbor: University Microfilms, 1973.

11 Abu-Zeid HA, Choi NW, Hsu PH. Factors associated with risk of cancer of the colon and rectum. Am ₹ Epidemiol 1981;114:442.

12 Haenszel W, Berg JW, Segi M, Kurihara M, Locke FB. Large-bowel cancer in Hawaiian Japanese. $\mathcal{F}$ Natl Cancer Inst 1973;51:1765-79.

13 Dales LG, Friedman GD, Ury HK, Grossman S, Williams SR. A case-control study of relationships of diet and other traits to colorectal cancer in American blacks. Am 7 Epidemiol 1979;109:132-44.

14 Higginson J. Etiological factors in gastrointestinal cancer in man. $\mathcal{F}$. Natl Cancer Inst 1966;37: $527-45$.

15 Graham S, Dayal H, Swanson M, Mittelman A, Wilkinson G. Diet in the epidemiology of cancer of colon and rectum. I Natl Cancer Inst 1978;61:709-14.

16 Jacobsen BK, Bjelke E, Kvåle G, Heuch I. Coffee drinking, mortality and cancer incidence: results from a Norwegian prospective study. I Natl Cancer Inst 1986;76:823-31.

17 Phillips RL, Snowdon DA. Dietary relationships with fatal colorectal cancer among Seventh-Day Adventists. F Natl Cancer Inst 1985;74:307-17.

18 Nomura A, Heilbrun LK, Stemmermann GN. Prospective study of coffee consumption and the risk of cancer. I Natl Cancer Inst 1986;76:587-90.

19 Bresalier RS, Kim YS. Diet and colon cancer. Putting the puzzle together. $N$ Engl $f$ Med 1985;313:1413-4.

20 Lowenfels AB. Is increased cholesterol excretion the link between low serum cholesterol and colon cancer? Nutr Cancer 1983;4:280-4.

21 McMichael AJ, Jensen OM, Parkin DM, Zaridze DG. Dietary and endogenous cholesterol and human cancer. Epidemiol Rec 1984;6:192-216.

22 Neugur AI Johnsen CM. Fink DJ. Serum cholesterol levels in adenomatous polyps and cancer of the colon. A case-control study. FAMA 1986;255:365-7.

23 Arnesen E, Huseby N-E, Brenn T, Try K. The Troms heart study: distribution of, and determinants for, gamma-glutamyltransferase in a free-living population. Scand $\mathcal{f}$ Clin Lab Invest 1986;46:63-70.

\section{HIV and sexual lifestyle}

Human immunodeficiency virus (HIV) is predominantly sexually transmitted, and fears are widespread that Britain may be on the brink of a major heterosexual epidemic similar to that in Africa. Authorities agree that there will be a spread into the heterosexual population, but they disagree about the likely extent.

In Western societies HIV is still virtually confined to specific risk groups: homosexual and bisexual men, past recipients of blood and blood products, and intravenous drug abusers and their sexual partners and offspring. Further spread depends on the amount of sexual contact between those from high risk groups and the rest of the population. Bisexual men and heterosexual intravenous drug abusers, especially those who work as prostitutes to pay for their habit, are an obvious risk to the general population. In the United States 13 of 49 men with the acquired immune deficiency syndrome (AIDS) and no recognised risk factors admitted to sexual contact with prostitutes.'

Homosexual practices seem to be the most efficient way of transmitting HIV and anal intercourse the most dangerous activity; the passive (anoreceptive) partner is much more at risk than the active partner. A recent study found no correlation between the presence of antibodies to HIV and either oral or rimming (oroanal sex), but the authors showed that fisting (brachioproctal intercourse) was a risk factor for the insertive partner. ${ }^{2}$ The virus can enter the body through breaches in the mucosa and is present in semen, so that these statistical indications do not exclude reliably the risk of HIV 